\author{
V. M. Buldenko', L. A. Kononets ${ }^{1}$, O. L. Kobzar¹, A. B. Drapailo², S. G. Vyshnevsky², \\ V. I. Kalchenko², A. I. Vovk ${ }^{1}$
}

${ }^{1}$ Institute of Bioorganic Chemistry and Petrochemistry of the National Academy of Sciences of Ukraine 1, Murmanska str., 02094, Kyiv-94, Ukraine. E-mail: vovk@bpci.kiev.ua

${ }^{2}$ Institute of Organic Chemistry of the National Academy of Sciences of Ukraine

\title{
The inhibitory potential of calixarenes against nucleotide pyrophosphatase/phosphodiesterase 1
}

It has been previously shown that phosphonic acids covalently attached to the macrocyclic platform of calix[4]arenes are capable of inhibiting alkaline phosphatases. In this paper the effects of the upper-rim functionalized calix[4]arenes on the activity of nucleotide pyrophosphatase/phosphodiesterase 1 (NPP1) have been examined.

Aim. To assess the inhibitory potential of calix[4]arene, thiacalix[4]arene and sulfonylcalix[4]arene derivatives against NPP1.

Results and discussion. It has been found that calix[4]arene, thiacalix[4]arene, and sulfonylcalix[4]arene tetrakismethylphosphonic acids inhibit NPP1 with the $\mathrm{IC}_{50}$ values in the micromolar range. The derivatives of sulfonylcalix[4]arene demonstrated the selectivity of inhibition of NPP1 over alkaline phosphatases. In addition, sulfonylcalix[4]arene tetrakismethylphosphonic acid was able to inhibit the nucleotide pyrophosphatase/phosphodiesterase activity of the human serum. The possible mechanism of the inhibition has been discussed.

Experimental part. The activity of NPP1 was monitored by spectrophotometry measuring the rate of hydrolysis of bis- $p$-nitrophenyl phosphate. The phosphodiesterase activity of the human serum was assessed in the presence of $p$-nitrophenyl ester of thymidine-5-monophosphate as a substrate. The homology model of the human NPP1 was generated based on the crystal structure of the murine enzyme. The molecular docking was performed using AutoDock 4.2.

Conclusions. The results obtained have shown the ability of sulfonylcalix[4]arene derivatives to inhibit the activity of NPP1 in vitro, including the nucleotide pyrophosphatase/phosphodiesterase activity in the human blood serum.

Key words: calix[4]arene; thiacalix[4]arene; sulfonylcalix[4]arene; nucleotide pyrophosphatase/phosphodiesterase 1; inhibition; molecular docking

\section{В. М. Булденко, Л. А. Кононець, О. Л. Кобзар, А. Б. Драпайло, С. Г. Вишневський,}

В. І. Кальченко, А. І. Вовк

Інгібіторний потенціал каліксаренів відносно нуклеотидопірофросфатази/

фоссфодіестерази 1

Раніше було показано, що фоссонові кислоти, ковалентно приєднані до макроциклічної платформи калікс[4]аренів, здатні інгібувати лужні фосфратази. В цій роботі вивчено вплив похідних калікс[4]арену на активність нуклеотидопірофоссратази /фосфоддіестерази 1 (NPP1).

Мета роботи - оцінити інгібіторний потенціал похідних калікс[4]арену, тіакалікс[4]арену та сульфонілкалікс[4]арену відносно NPP1.

Результати та їх обговорення. Встановлено, що калікс[4]арен-, тіакалікс[4]арен- та сульфонілкалікс[4]арен-тетракіс-метилфосфонові кислоти інгібують NPP1 зі значеннями IC 50 в мікромолярному діапазоні. Інгібування NPP1 похідними сульфонілкалікс[4]арену було селективним відносно лужних фросфатаз. Крім того, сульфонілкалікс[4]арен-тетракіс-метилфоссронова кислота здатна інгібувати нуклеотидопірофросфратазну/фросфодіестеразну активність людської сироватки. Обговорюється можливий механізм інгібування.

Експерименальна частина. Активність NPP1 контролювали спектрофотометрично за швидкістю гідролізу біс-п-нітрофренілфосфату. Нуклеотидопірофросфатазну/фоссфодіестеразну активність людської сироватки оцінювали з використанням п-нітрофренілового естеру тимідин-5-монофосфату як субстрату. Гомологічна модель людської NPP1 була згенерована на основі кристалічної структури мишачого ферменту. Молекулярний докінг проводили за допомогою програми AutoDock 4.2.

Висновки. Отримані результати показали здатність похідних сульфонілкалікс[4]арену інгібувати активність NPP1 in vitro, в тому числі нуклеотидопірофосфратазну/фросфодіестеразну активність сироватки крові людини.

Ключові слова: калікс[4]арен; тіакалікс[4]арен; сульфонілкалікс[4]арен; нуклеотидопірофоссратаза/ фоссфодіестераза 1; інгібування; молекулярний докінг

\section{В. Н. Булденко, Л. А. Кононец, А. Л. Кобзарь, А. Б. Драпайло, С. Г. Вишневский,}

В. И. Кальченко, А. И. Вовк

Ингибиторный потенциал каликсаренов относительно нуклеотидпирофосфатазы/ фосфодиэстеразы 1

Ранее было показано, что фосфоновые кислоты, ковалентно присоединенные к макроциклической платформе каликс[4]аренов, способны ингибировать щелочные фоссратазы. В настоящей работе исследовано влияние производных каликс[4]арена на активность нуклеотидпирофросфатазы /фросфодиэстеразы 1 (NPP1).

Цель работы - оценить ингибиторный потенциал производных каликс[4]арена, тиакаликс[4]арена и сульфронилкаликс[4] арена относительно NPP1. 
Результаты и их обсуждение. Установлено, что каликс[4]арен-, тиакаликс[4]арен- и сульфонилкаликс[4]арен-тетракис-метилфосфоновые кислоты ингибируют NPP1 со значениями IC ${ }_{50}$ в микромолярном диапазоне. Ингибирование NPP1 производными сульфонилкаликс[4]арена было селективным относительно щелочных фоссфатаз. Кроме того, сульфонилкаликс[4]арен-тетракис-метилфосфоновая кислота способна ингибировать фросфодиэстеразную активность человеческой сыворотки. Обсуждается возможный механизм ингибирования.

Экспериментальная часть. Активность NPP1 контролировали спектрофотометрически по скорости гидролиза бис-п-нитрофенилфосфрата. Нуклеотидпирофосфатазную/фросфодиэстеразную активность человеческой сыворотки оценивали в присутствии п-нитрофенилового эфира тимидин-5-монофосфрата в качестве субстрата. Гомологическая модель человеческой NPP1 была сгенерирована на основе кристаллической структуры мышиного фермента. Молекулярный докинг проводился с помощью программы AutoDock 4.2.

Выводы. Полученные результаты показали способность производных сульфонилкаликс[4]арена ингибировать in vitro NPP1, в том числе нуклеотидпирофосфатазную/фосффодиэстеразную активность сыворотки крови человека.

Ключевые слова: каликс[4]арен; тиакаликс[4]арен; сульфонилкаликс[4]арен; нуклеотидпирофросфратаза/фросфродиэстераза 1; ингибирование; молекулярный докинг

Nucleotide pyrophosphatase/phosphodiesterase 1 (NPP1, EC 3.1.4.1) represents a group of enzymes, which catalyze the hydrolysis of phosphodiester bonds of various substrates, including nucleotides [1]. NPP1 is a membrane bound glycoprotein presented in many tissues and involved in the regulation of cell differentiation, bone and tissue mineralization, and cellular signaling [2]. The abberant activity of NPP1 can result in chrondrocalcinosis, pathological calcification, osteoarthritis and other diseases [3]. In this connection, NPP1 is considered to be a possible pharmacological target for novel therapeutics.

Several natural and synthetic compounds are described as inhibitors of NPP1 $[1,4]$. As an example, potent non-nucleotide inhibitors of NPP1 were represented by polyoxometalates [5], polysaccharides [6], glycosides [7], as well heterocyclic compounds [8,9].

Taking into account the fact that NPP1 belongs to the alkaline phosphatase superfamily, and there

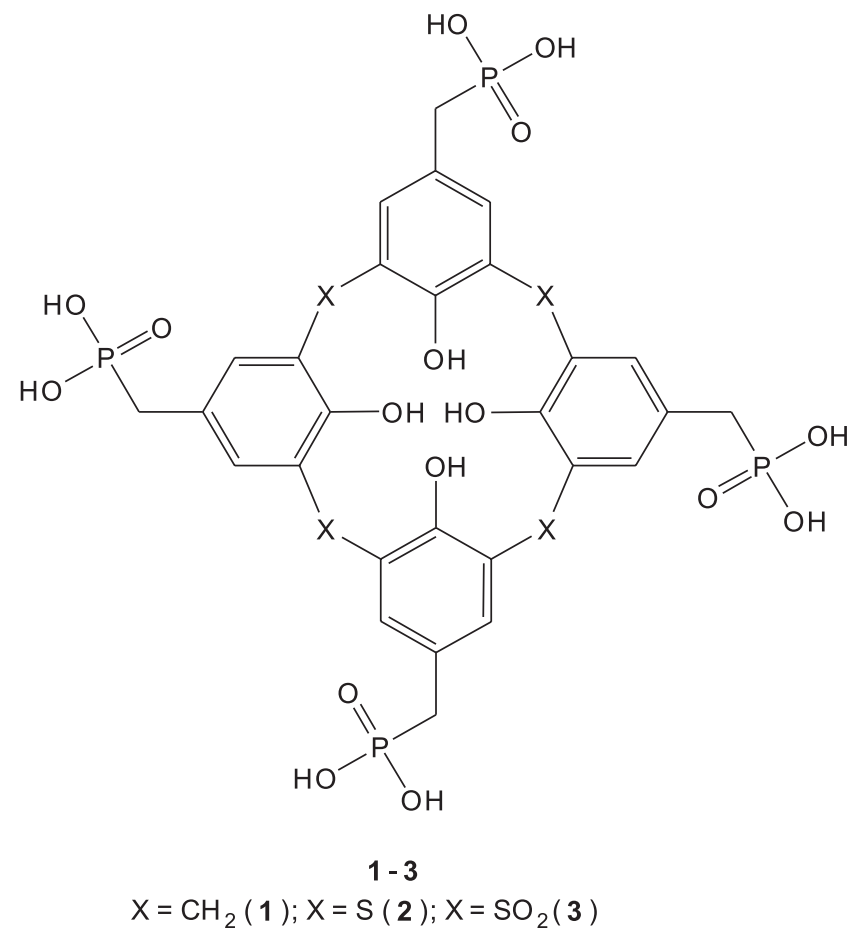

is certain similarity in the structure of active sites of these enzymes [10], we assumed that the strategy of phosphatase inhibition by calix [4] arenes [11-13] might be used for searching for inhibitors of NPP1. The present study was undertaken in order to assess the inhibitory potential of calix[4]arenes, thiacalix[4]arenes, and sulfonylcalix[4]arenes 1-6 against NPP1 (Fig. 1).

For assessment of functionalized calix[4]arenes as inhibitors of NPP1 and alkaline phosphatases, bis$p$-nitrophenyl phosphate and $p$-nitrophenyl phosphate were used as substrates, respectively. As is seen from Tab. 1, calix[4] arene and thiacalix[4] arene tetrakismethylphosphonic acids $\mathbf{1}$ and $\mathbf{2}$ showed approximately the same inhibition effects on the activities of NPP1 and alkaline phosphatase from the bovine intestinal mucosa with the micromolar values of $\mathrm{IC}_{50}$. The inhibition effects of these compounds on alkaline phosphatase from the human placenta were not significant. At the same time, methylphosphonic acid

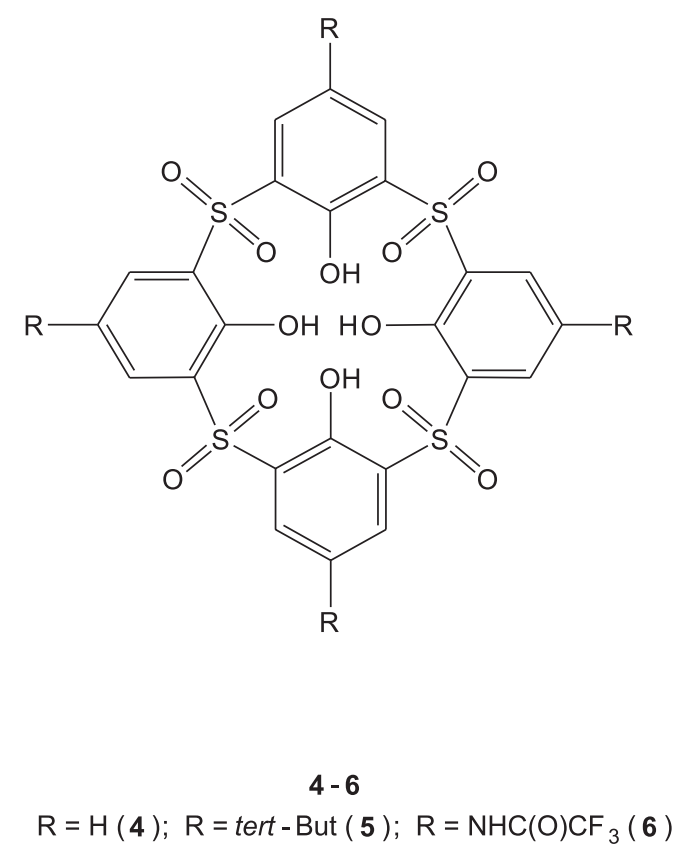

Fig. 1. Structures of calix[4]arene, thiacalix[4]arene, and sulfonylcalix[4]arene derivatives 1-6 
Table 1

Calix[4]arene, thiacalix[4]arene, and sulfonylcalix[4]arene phosphonic derivatives 1-6 as inhibitors NPP1 and alkaline phosphatases*

\begin{tabular}{|c|c|c|c|c|c|}
\hline \multirow{3}{*}{ Inhibitor } & \multicolumn{3}{|c|}{ NPP1 } & \multirow{2}{*}{$\begin{array}{c}\text { Alkaline phosphatase } \\
\text { from the bovine } \\
\text { mucosa }\end{array}$} & \multirow{2}{*}{$\begin{array}{l}\text { Alkaline phosphatase } \\
\text { from the human } \\
\text { placenta }\end{array}$} \\
\hline & \multirow[t]{2}{*}{$\mathrm{IC}_{50}, \mathrm{\mu M}$} & \multirow[t]{2}{*}{$K_{\mathrm{i}}, \mu \mathrm{M}$} & \multirow[t]{2}{*}{$K_{\mathrm{i}}^{\prime}, \mu \mathrm{M}$} & & \\
\hline & & & & $I C_{50}, \mu M$ & $I C_{50}, \mu \mathrm{M}$ \\
\hline 1 & $0.37 \pm 0.06$ & $0.34 \pm 0.03$ & $0.63 \pm 0.23$ & $0.43 \pm 0.04$ & $>100$ \\
\hline 2 & $0.36 \pm 0.08$ & $0.21 \pm 0.07$ & $0.30 \pm 0.06$ & $0.27 \pm 0.02$ & $>100$ \\
\hline 3 & $0.44 \pm 0.08$ & $0.39 \pm 0.12$ & - & n. $a^{* *}$ & n.a \\
\hline 4 & $2.3 \pm 0.03$ & & & $>50$ & n.a \\
\hline 5 & $8.4 \pm 1.8$ & & & n.a & n.a \\
\hline 6 & $0.2 \pm 0.07$ & & & n.a & n.a \\
\hline
\end{tabular}

Notes: $*-\mathrm{IC}_{50}$ values are the means of $2-3$ assays \pm standard deviations; $* *$ - not active at $20 \mu \mathrm{M}$.

derivative 3 bearing the sulfonylcalix[4]arene skeleton (Fig. 1) demonstrated the inhibitory activity only against NPP1 and did not affect the activity of alkaline phosphatases from the bovine mucosa and from the human placenta. The results obtained indicates that selectivity of sulfonylcalix[4] arene derivative 3 as an inhibitor of NPP1 can be attributed to the modified macrocyclic scaffold.

According to Lineweaver-Burk plots the effect of inhibitors $\mathbf{1}$ and $\mathbf{2}$ on the activity of NPP1 are in agreement with a mixed-type inhibition. The apparent $K_{\mathrm{i}}$ and $K_{\mathrm{i}}$ values are of $0.34 \mu \mathrm{M}$ and $0.63 \mu \mathrm{M}$ (compound 1) and $0.21 \mu \mathrm{M}$ and $0.30 \mu \mathrm{M}$ (compound 2), respectively. The mechanism of NPP1 inhibition by methylphosphonic acids $\mathbf{1}$ and $\mathbf{2}$ involves the binding of the inhibitor to the enzyme with formation of enzymeinhibitor and enzyme-substrate-inhibitor complexes. On the contrary, inhibition of NPP1 by sulfonylcalix[4] arene tetrakismethylphosphonic acids $\mathbf{3}$ was found to be of competitive type with the $K_{\mathrm{i}}$ value of $0.39 \mu \mathrm{M}$
(Fig. 2, C). This type of inhibition suggests that the sulfonylcalix[4]arene inhibitor binds to the enzyme only in the substrate binding site.

Our further efforts for designing inhibitors of NPP1 were directed towards sulfonylcalix[4]arene $\mathbf{4}$ and compounds $\mathbf{5}$ and $\mathbf{6}$ with non-ionogenic substituents (Fig. 1). Among them, tetrakis-tert-butyl sulfonylcalix[4]arene $\mathbf{5}$ showed the lowest inhibition effect, while tetrakis3-fluormethylacetamide sulfonylcalix[4]arene $\mathbf{6}$ had the $\mathrm{IC}_{50}$ value of $0.2 \mu \mathrm{M}$ with selectivity over alkaline phosphatases from the bovine mucosa and from the human placenta (Tab. 2).

The nucleotide pyrophosphatases/phosphodiesterase activity of the human serum was assessed in the presence of sulfonylcalix[4] arene 1-3 using thymidine-5-monophosphate- $p$-nitrophenyl ester as a substrate [14]. To the best our knowledge, sulfonylcalix[4]arene tetrakismethylphosphonic acid 3 exhibited the inhibitory effect on the NPP1 activity of the human serum preventing the hydrolysis of the

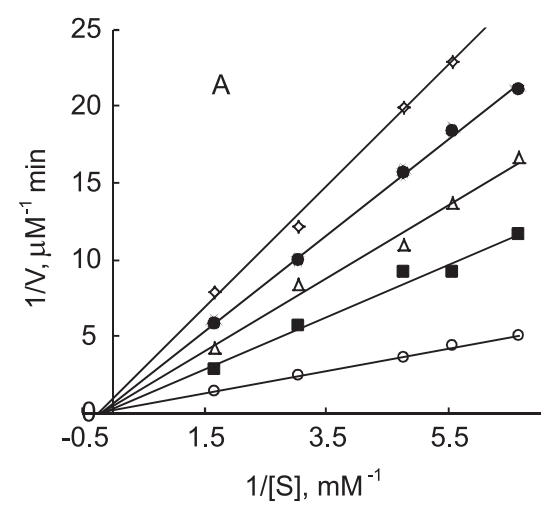

Concentrations of inhibitor $1(A)$ :

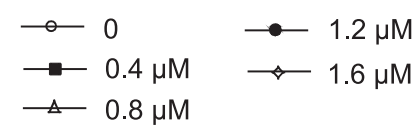

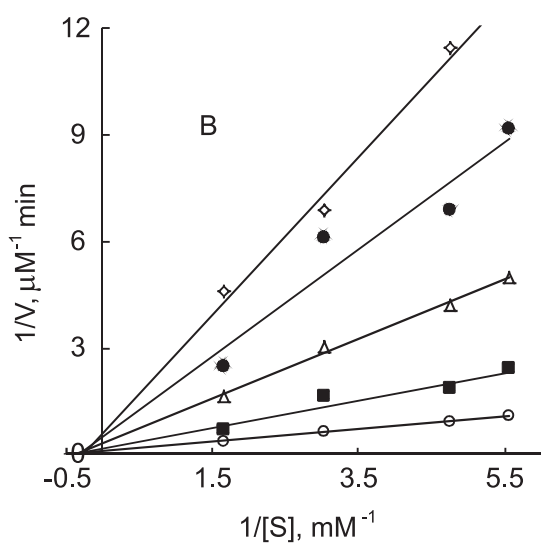

Concentrations of inhibitor $2(B)$ :

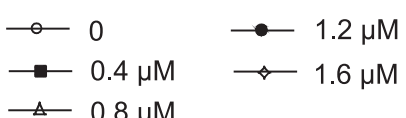

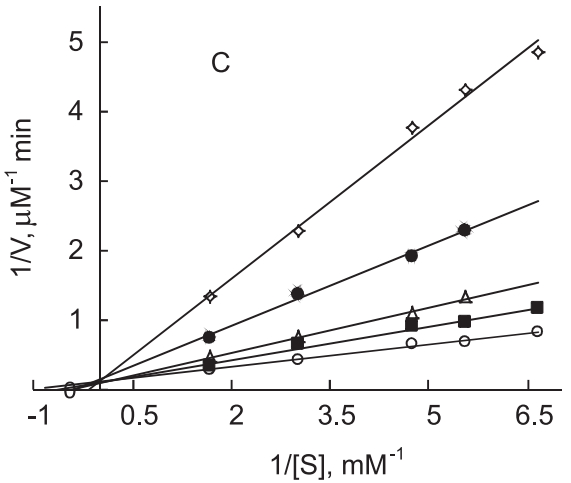

Concentrations of inhibitor $3(\mathrm{C})$ :

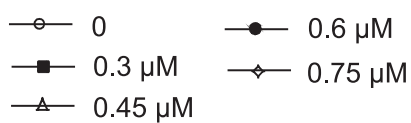

Fig. 2. Lineweaver-Burk plots for inhibition of snake venom NPP1 
Table 2

Free energy of binding of the conformers of calix[4] arene derivatives 1-3 into the active site of the homology model of the human NPP1

\begin{tabular}{|l|c|c|c|}
\hline \multirow{2}{*}{ Conformer } & \multicolumn{3}{|c|}{$\Delta \mathrm{G}(\mathrm{kcal} / \mathrm{mol})$} \\
\cline { 2 - 4 } & $\mathbf{1}$ & $\mathbf{2}$ & $\mathbf{3}$ \\
\hline cone & -6.53 & -7.25 & -9.73 \\
\hline partial cone & -6.66 & -9.86 & -10.27 \\
\hline 1,2-alternate & -6.18 & -8.9 & -8.71 \\
\hline 1,3-alternate & -8.38 & -8.48 & -10.29 \\
\hline
\end{tabular}

substrate. At the same time, compounds 1, 2, 4-6 did not show sufficient effects (Fig. 3).

To get insights into a possible binding mechanism of compounds 1-3 the molecular docking studies were performed using the homology model of the human NPP1 based on the X-ray structure of its murine ortholog. Four conformers [15] for compounds 1-3 were docked to the homology model of the human NPP1 using Autodock 4.2. The docking results suggest that the most preferable for binding are 1,3-alternate of calix [4] arene derivative $\mathbf{1}$, the partial cone of thiacalix[4] arene derivative $\mathbf{2}$, and both partial cone and 1,3-alternate of sulphonylcalix[4]arene derivative 3 (Tab. 2).

Further examination of the docking results showed that compounds 1-3 were oriented towards two zinc ions of the enzyme. The differences in the inhibitory activity (Fig. 3) might be explained by formation of hydrogen bonds between $\mathrm{SO}_{2}$-bridged groups of the sulfonylcalix[4] arene platform of compound 3 and amino acid residues at the catalytic center of NPP1 (Fig. 4). One of $\mathrm{SO}_{2}$-groups of sulfonylcalix[4]arene formed hydrogen bonds with amino acid residues of His535, His380, Thr256, Asn277 located near metal ions. Other $\mathrm{SO}_{2}$-groups had H-bonds with Ser377, Lys291, and Tyr451. The OH-group on the lower rim of the macrocycle provides the H-bond with Lys528. The phosphonic acid groups interact with His535, Gln519, Leu290, Lys291, Lys291, and Ser377. The oxygen of the phosphonate group of the inhibitor and two aromatic rings of the sulfonylcalix [4]arene platform were involved in the interaction with His535, Tyr340, and Lys528, respectively.

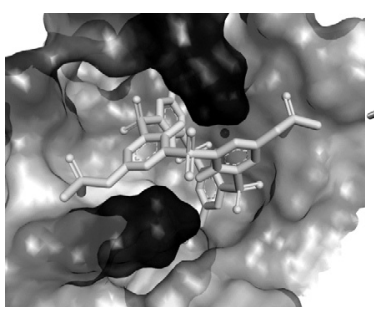

$\mathbf{A}$

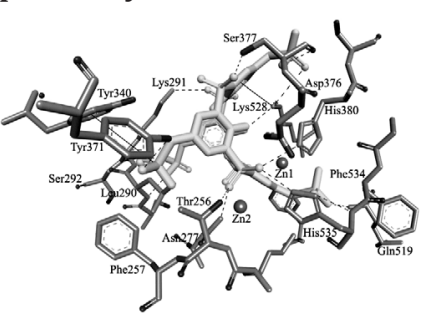

Fig.4. The posible binding mode of compound 3 at the active site of the homology model of human NPP1: general view (A) and amino acids involved in the complex formation (B)

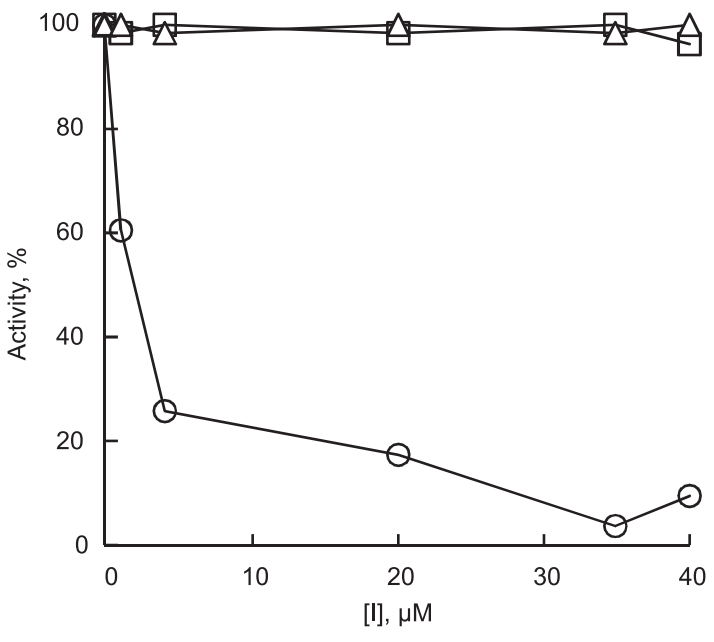

$\square$ Presence of compound $1 \quad \triangle$ Presence of compound 2

$\bigcirc$ Presence of compound 3

Fig. 3. The pyrophosphatase/phosphodiesterase activity of the human serum

\section{Experimental part}

\section{In vitro study of NPP1 inhibition}

Phosphodiesterase 1 from Bothrops atrox (type V), alkaline phosphatase from the bovine intestinal mucosa (type VII-L), alkaline phosphatase from the human placenta (type XXIV), human sera, bis- $p$-nitrophenyl phosphate, $p$-nitrophenyl phosphate, thymidine-5-monophosphate- $p$-nitrophenyl ester were purchased from Sigma-Aldrich.

The effect of calix[4]arene derivatives on the rate of hydrolysis of bis- $p$-nitrophenylphosphate catalyzed by NPP1 was assayed in $0.05 \mathrm{M}$ tris-HCl buffer (pH 8.8) with 1 vol \% of dimethyl sulfoxide. The mixture was incubated for $5 \mathrm{~min}$ at $25^{\circ} \mathrm{C}$ in a buffer solution with the inhibitor. The reaction was initiated by addition of the enzyme. The total volume of the reaction mixture was $1.5 \mathrm{ml}$. The rate of hydrolysis of bis- $p$-nitrophenyl phosphate was measured by following the change in absorption of $p$-nitrophenol at $410 \mathrm{~nm}$ (the molar excitation coefficient of $18300 \mathrm{M}^{-1} \mathrm{~cm}^{-1}$ ). The value of $\mathrm{IC}_{50}$ was calculated as the concentration of the inhibitor, which reduced the rate of the enzymatic reaction by $50 \%$.

For the study of the alkaline phosphatase activity, the reaction mixture contained $0.1 \mathrm{M}$ Tris- $\mathrm{HCl}$ buffer ( $\mathrm{pH}$ 9), $0.5 \mathrm{mM} p$-nitrophenylphosphate as a substrate, and the inhibitor had been preliminarily thermostated for $5 \mathrm{~min}$ at $25^{\circ} \mathrm{C}$. The inhibitors 1-3 were preliminary dissolved in dimethyl sulfoxide ( 2 vol \% in the reaction mixture).

The nucleotide pyrophosphatases/phosphodiesterase activity of the human serum was assayed in $0.05 \mathrm{M}$ buffer solution ( $\mathrm{pH}$ 9) containing $1 \mathrm{vol} \%$ of dimethyl sulfoxide, $0.2 \mathrm{mM}$ thymidine-5-monophosphate- $p$-nitrophenyl ester, $4.5 \mathrm{mM} \mathrm{MgCl}_{2}$. The mixture with the inhibitor was incubated for $5 \mathrm{~min}$ at $37^{\circ} \mathrm{C}$, and the reaction was initiated by addition of the human serum. 


\section{Molecular docking}

The docking calculations were carried by AutoDock 4.2 [16]. For the preliminary preparation of docking files, the program AutoDockTools was used. Three dimensional structures of the inhibitors were optimized in the MMFF94s force field by the program Avogadro [17]. The homology model of the human NPP1 enzyme was generated based on the crystal structure of the mouse NPP1 (PDB code 4GTW) by the Swiss-Model server [18-20]. The sequence of the human NPP1 was retrieved from accession number P22413 of the UniProtKB server. The energy minimization of the model was performed by SPD viewer.

\section{Synthesis of calixarenes}

Calix[4]arene, thiacalix[4]arene, and sulfonylcalix [4]arene methylphosphonic acids 1-3 were synthesized according to the protocols previously developed [21-23]. For the synthesis of sulfonylcalix[4]arene 4 and its tetrakis-tert-butyl derivative 5 the procedures previously developed were used $[24,25]$. Compound $\mathbf{6}$ was obtained by the oxidation reaction of thiacalix[4]arene tetrakis-3-fluormethylacetamide with $\mathrm{NaBO}_{3} \times 4 \mathrm{H}_{2} \mathrm{O}$ in the presence of absolute trifluoroacetic acid.

The synthesis of 5,11,17,23-tetrakis(trifluoromethylacetamide)-25,26,27,28-tetrahydroxysulfonylcalix[4]arene 6. To the solution of $0.5 \mathrm{~g}(0.53 \mathrm{mM})$ of 5,11,17,23-tetrakis(trifluoromethylacetamide)$25,26,27,28$-tetrahydroxythiacalix [4]arene in absolute trifluoroacetic acid ( $5 \mathrm{ml})$ add $1.0 \mathrm{~g}(6.5 \mathrm{mM})$ $\mathrm{NaBO}_{3} \times 4 \mathrm{H}_{2} \mathrm{O}$. Stir the reaction mixture at $50{ }^{\circ} \mathrm{C}$ for $24 \mathrm{~h}$, and then pour the reaction mass into a cooled solution of $5 \mathrm{~N} \mathrm{H}_{2} \mathrm{SO}_{4}(20 \mathrm{ml})$. Filter the precipitate and wash with water $(2 \times 10 \mathrm{ml})$. Dry the resulting 5,11,17,23-tetrakis(trifluoromethylacetamide)-25,26, 27,28-tetrahydroxysulfonylcalix[4]arene 6 (the crystalline substance of a white color $)$ in vacuo $(0.10 \mathrm{~mm} \mathrm{Hg})$ at $60{ }^{\circ} \mathrm{C}$ for $2 \mathrm{~h}$.

The yield $-0.42 \mathrm{~g}(74 \%)$. M. p. $>300{ }^{\circ} \mathrm{C} .{ }^{1} \mathrm{H}$ NMR (400 MHz, DMSO-d ${ }_{6}$ ): $\delta 8.45$ (s, 8H, H-arom.), 11.54 (s, $4 \mathrm{H}, \mathrm{NH}) ;{ }^{19} \mathrm{~F}$ NMR $\left(400 \mathrm{MHz}\right.$, DMSO- $\left.d_{6}\right): \delta-74.54 ;{ }^{13} \mathrm{C}$ NMR (400 MHz, DMSO- $d_{6}$ ): 111.39; $114.26 ; 117.13$; $119.99\left(\mathrm{~m}, \mathrm{CF}_{3}, 1 \mathrm{~J}_{\mathrm{FC}} 288 \mathrm{~Hz}\right) ; 126.80 ; 127.07 ; 130.16$ (C-arom); $154.79\left(\mathrm{~m}, \mathrm{COCF}_{3},{ }^{2} \mathrm{~J}_{\mathrm{CC}} 37 \mathrm{~Hz}\right)$. Anal. calcd for $\mathrm{C}_{32} \mathrm{H}_{16} \mathrm{~F}_{12} \mathrm{~N}_{4} \mathrm{O}_{16} \mathrm{~S}_{4}, \%$ : C, 35.96; H, 1.51; F, 21.33; N, 5.24; S, 12.00. Found, \%: C, 36.16; H, 1.71; F, 21.05; N, 5.04; S, 11.85 .

For the synthesis of 5,11,17,23-tetrakis(trifluoromethylacetamide)-25,26,27,28-tetrahydroxythia-

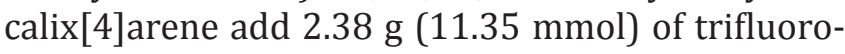
methylacetic anhydride and $1.2 \mathrm{~g}(11.86 \mathrm{mmol})$ of triethylamine to the suspension of $0.9 \mathrm{~g}(1.29 \mathrm{mM})$ of chlorhydrate aminothiacalix [4]arene [26] in absolute tetrahydrofuran $(20 \mathrm{ml})$ at the room temperature with stirring. Stir the reaction mixture at room temperature for $24 \mathrm{~h}$, filter the resulting precipitate, and evaporate the solution on a rotary evaporator. To the residue obtained add $10 \mathrm{ml}$ of water, and filter the resulting precipitate. Dry the resulting 5,11,17,23-tetrakis (trifluoromethylacetamide)-25,26,27,28-tetrahydroxythiacalix[4] arene (the crystalline substance of a white color) in vacuo $(0.05 \mathrm{~mm} \mathrm{Hg})$ at $60^{\circ} \mathrm{C}$ for $2 \mathrm{~h}$. The yield $-0.75 \mathrm{~g}(62.5 \%)$. M. p. $>300^{\circ} \mathrm{C}$ (decomp.). ${ }^{1} \mathrm{H}$ NMR (400 MHz, DMSO- $d_{6}$ ): $\delta 7.85$ (s, 8H, H-arom.), $11.09(\mathrm{~s}, 4 \mathrm{H}, \mathrm{NH}) ;{ }^{19} \mathrm{~F}$ NMR (400 MHz, DMSO- $\left.d_{6}\right)$ : $\delta 74.36 ;{ }^{13} \mathrm{C}$ NMR (400 MHz, DMSO- $d_{6}$ ): $111.49 ; 114.35$; 117.23; $120.09\left(\mathrm{~m}, \mathrm{CF}_{3},{ }^{1} \mathrm{~J}_{\mathrm{FC}} 288 \mathrm{~Hz}\right) ; 120.94 ; 127.89$; 128.85 (C-arom.); 154.05 (m, $\mathrm{COCF}_{3},{ }^{2} \mathrm{~J}_{\mathrm{CC}} 37 \mathrm{~Hz}$ ). Anal. calcd for $\mathrm{C}_{32} \mathrm{H}_{16} \mathrm{~F}_{12} \mathrm{~N}_{4} \mathrm{O}_{8} \mathrm{~S}_{4}, \%$ : C, 40.86; H, 1.71; F, 24.24; N, 5.96; S, 13.63. Found, \%: C, 41.12; H, 1.83; F, 24.07; N, 6.15; S, 13.45 .

\section{Conclusions}

1. Calix[4]arene and thiacalix[4]arene derivatives are found to be effective inhibitors of NPP1 with the micromolar $\mathrm{IC}_{50}$ values.

2. The results obtained have shown the ability of functionalized sulfonylcalix[4]arenes to selectively inhibit the activity of NPP1 in vitro, including the nucleotide pyrophosphatase/phosphodiesterase activity in the human blood serum.

Conflict of Interests: authors have no coflict of interests to declare.

\section{References}

1. Al-Rashida, M. Therapeutic potentials of ecto-nucleoside triphosphate diphosphohydrolase, ecto-nucleotide pyrophosphatase/phosphodiesterase, ecto-5'-nucleotidase, and alkaline phosphatase inhibitors / M. al-Rashida, J. Iqbal // Med. Res. Rev. - 2013. - Vol. 34, Issue 4. - P. 703-743. doi: $10.1002 /$ med.21302

2. Nucleotide pyrophosphatases/phosphodiesterases on the move / M. Bollen, R. Gijsbers, H. Ceulemans et al. // Crit. Rev. Biochem. Mol. Biol. 2000. - Vol. 35, Issue 6. - P. 393-432. doi: 10.1080/10409230091169249

3. Goding, J. W. Physiological and pathophysiological functions of the ecto-nucleotide pyrophosphatase/phosphodiesterase family / J. W. Goding B. Grobben, H. Slegers // Biochim. Biophys. Acta. - 2003. - Vol. 1638, Issue 1. - P. 1-19. doi: 10.1016/S0925-4439(03)00058-9

4. Substrate-dependence of competitive nucleotide pyrophosphatase/phosphodiesterase1 (NPP1) inhibitors/ S. Y. Lee, S. Sarkar, S. Bhattarai et al. // Frontiers Pharm. - 2017. - Vol. 8. doi: 10.3389/fphar.2017.00054

5. Polyoxometalates - potent and selective ecto-nucleotidase inhibitors / S. Y. Lee, A. Fiene, W. Li et al. // Biochem. Pharm. - 2015. - Vol. 93, Issue 2. P. 171-181. doi: 10.1016/j.bcp.2014.11.002

6. Lee, S. Y. Nucleotide pyrophosphatase/phosphodiesterase 1 (NPP1) and its inhibitors / S. Y. Lee, C. E. Müller // Med. Chem. Comm. - 2017. - Vol. 8, Issue 5. - P. 823-840. doi: 10.1039/C7MD00015D

7. Phenolic glycosides, a new class of human recombinant nucleotide pyrophosphatase phosphodiesterase-1 inhibitors / M. I. Choudhary, N. Fatima, M. A. Abbasi et al. // Bioorg. Med. Chem. - 2004. - Vol. 12, Issue 22. - P. 5793-5798. doi: 10.1016/j.bmc.2004.08.035

8. 1,3,4-Oxadiazole-2 (3H)-thione and its analogues : A new class of non-competitive nucleotide pyrophosphatases/phosphodiesterases 1 inhibitors / K. M. Khan, N. Fatima, M. Rasheed et al. // Bioorg. Med. Chem. - 2009. - Vol. 17, Issue 22. - P. 7816-7822. doi: 10.1016/j.bmc.2009.09.011

9. Synthesis of triazole Schiff bases : Novel inhibitors of nucleotide pyrophosphatase/phosphodiesterase-1 / K. M. Khan, S. Siddiqui, M. Saleem et al. // Bioorg. Med. Chem. - 2014. - Vol. 22, Issue 22. - P. 6509-6514. doi: 10.1016/j.bmc.2014.08.032 
10. Structural and functional comparisons of nucleotide pyrophosphatase/phosphodiesterase and alkaline phosphatase : implications for mechanism and evolution / J. G. Zalatan, T. D. Fenn, A. T. Brunger, D. Herschlag // Biochem. - 2006. - Vol. 45, Issue 32. - P. 9788-9803. doi: 10.1021/bi060847t

11. Calix[4]arene methylenebisphosphonic acids as calf intestine alkaline phosphatase inhibitors / A. I. Vovk, V. I. Kalchenko, S. A. Cherenok et al. // Org. Biomol. Chem. - 2004. - Vol. 2, Issue 21. - 3162 p. doi: 10.1039/B409526]

12. Inhibition of Yersinia protein tyrosine phosphatase by phosphonate derivatives of calixarenes / A. I. Vovk, L. A. Kononets, V. Yu. Tanchuk et al. // Bioorg. Med. Chem. Let. - 2010. - Vol. 20, Issue 2. - P. 483-487. doi: 10.1016/j.bmcl.2009.11.126

13. Thiacalix [4]arene as molecular platform for design of alkaline phosphatase inhibitors / A. I. Vovk, L. A. Kononets, V. Yu. Tanchuk et al. // J. Incl. Phenom. Macrocycl. Chem. - 2010. - Vol. 66, Issue 3-4. - P. 271-277. doi: 10.1007/s10847-009-9607-9

14. Kinetic and biochemical characterization of an ecto-nucleotide pyrophosphatase/phosphodiesterase (EC 3.1. 4.1) in cells cultured from submandibular salivary glands of rats / S. L. Henz, C. R. Fürstenau, R. A. Chiarelli, J. J. F. Sarkis // Arch. Oral Biol. - 2007. - Vol. 52, Issue 10. P. 916-923. doi: 10.1016/j.archoralbio.2007.03.006

15. Conformational and energetical structures of sulfonylcalix[4]arene, p-tert-butylsulfonylcalix[4]arene and their zinc complexes / B. Wanno, W. Sang-aroon, T. Tuntulani et al. // J. Mol. Struct. (Theochem.) - 2003. - Vol. 629, Issue 1-3. - P. 137-150. doi: 10.1016/S0166-1280(03)00135-0

16. A semiempirical free energy force field with charge-based desolvation / R. Huey, G. M. Morris, A. J. Olson, D. S. Goodsell // J. Comput. Chem. 2007. - Vol. 28, Issue 6. - P. 1145-1152. doi: 10.1002/jcc.20634

17. Avogadro : an advanced semantic chemical editor, visualization, and analysis platform / M. D. Hanwell, D. E. Curtis, D. C. Lonie et al. // Cheminform. - 2012. - Vol. 4, Issue 1. - 17 p. doi: 10.1186/1758-2946-4-17

18. Swiss-model : modelling protein tertiary and quaternary structure using evolutionary information / M. Biasini, S. Bienert, A. Waterhouse et al. // Nucleic Acids Res. - 2014. - Vol. 42, Issue W 1. - P. W252-W258. doi: 10.1093/nar/gku340

19. Sali, A. Comparative protein modelling by satisfaction of spatial restraints / A. Sali, T. Blundell // J. Mol. Biol. - 1993. - Vol. 234, Issue 3. P. 779-815. doi: 10.1006/jmbi.1993.1626

20. Structure of NPP1, an ectonucleotide pyrophosphatase/phosphodiesterase involved in tissue calcification / S. Jansen, A. Perrakis, C. Ulens et al. // Structure - 2012. - Vol. 20, Issue 11. - P. 1948-59. doi: 10.1016/j.str.2012.09.001

21. Chloromethylation of calixarenes and synthesis of new water soluble macrocyclic hosts / M. Almi, A. Arduini, A. Casnati et al. // Tetrahedron. 1989. - Vol. 45, Issue 7. - P. 2177-2182. doi: 10.1016/S0040-4020(01)80077-6

22. Upper rim substituted thiacalix[4]arenes / O. Kasyan, D. Swierczynski, A. Drapailo et al. // Tetrahedron Let. - 2003. - Vol. 44, Issue 38. P. 7167-7170. doi: 10.1016/S0040-4039(03)01809-4

23. Thia- and sulfonyl-calix[4]arene methylphosphonous acids : Synthesis, structure, and amino acids binding / S. G. Kharchenko, A. B. Drapailo, O. I. Kalchenko et al. // Phosph. Sulfur Silicon. - 2013. - Vol. 188, Issue 1-3. - P. 243-248. doi: 10.1080/10426507.2012.741164

24. Selective oxidation of thiacalix[4]arenes to the sulfinyl- and sulfonilcalix[4] arenes and their coordination ability to metal ions / N. Iki, H. Kumagai, N. Morohashi et al. // Tetrahedron Let. - 1998. - Vol. 39, Issue 41. - P. 7559-7562. doi: 10.1016/S0040-4039(98)01645-1

25. Facile synthesis of $p$-tert-butylthiacalix[4]arene by the reaction $p$-tert-butylphenol with elemental sulfur in the presence of base / H. Kumagai, M. Hasegawa, S. Miyanari et al. // Tetrahedron Let. - 1997. - Vol. 38, Issue 22. - P. 3971-3972. doi: 10.1016/S0040-4039(97)00792-2

26. Hydrogen-bonded dimers of a thiacalixarene substituted by carbamoylmethylphosphineoxide groups at the wide rim / O. Kasyan, V. Kalchenko, M. Bolte, M. Bohmer // Chem. Commun. - 2006. - Vol. 18. - P. 1932-1934. doi: 10.1039/B601016D

\section{References}

1. Al-Rashida, M., Iqbal, J. (2013). Therapeutic Potentials of Ecto-Nucleoside Triphosphate Diphosphohydrolase, Ecto-Nucleotide Pyrophosphatase/Phosphodiesterase, Ecto-5'-Nucleotidase, and Alkaline Phosphatase Inhibitors. Medicinal Research Reviews, 34 (4), 703-743. doi: 10.1002/med.21302

2. Bollen, M., Gijsbers, R., Ceulemans, H., Stalmans, W., Stefan, C. (2000). Nucleotide Pyrophosphatases/Phosphodiesterases on the Move. Critical Reviews in Biochemistry and Molecular Biology, 35 (6), 393-432. doi: 10.1080/10409230091169249

3. Goding, J. W., Grobben, B., Slegers, H. (2003). Physiological and pathophysiological functions of the ecto-nucleotide pyrophosphatase/phosphodiesterase family. Biochimica et Biophysica Acta (BBA) - Molecular Basis of Disease, 1638 (1), 1-19. doi: 10.1016/s0925-4439(03)00058-9

4. Lee, S.-Y., Sarkar, S., Bhattarai, S., Namasivayam, V., De Jonghe, S., Stephan, H., Müller, C. E. (2017). Substrate-Dependence of Competitive Nucleotide Pyrophosphatase/Phosphodiesterase1 (NPP1) Inhibitors. Frontiers in Pharmacology, 8. doi: 10.3389/fphar.2017.00054

5. Lee, S.-Y., Fiene, A., Li, W., Hanck, T., Brylev, K. A., Fedorov, V. E., Müller, C. E. (2015). Polyoxometalates-Potent and selective ecto-nucleotidase inhibitors. Biochemical Pharmacology, 93 (2), 171-181. doi: 10.1016/j.bcp.2014.11.002

6. Lee, S.-Y., Müller, C. E. (2017). Nucleotide pyrophosphatase/phosphodiesterase 1 (NPP1) and its inhibitors. MedChemComm, 8 (5), 823-840. doi: $10.1039 / \mathrm{c} 7 \mathrm{md} 00015 \mathrm{~d}$

7. Choudhary, M. I., Fatima, N., Abbasi, M. A., Jalil, S., Ahmad, V. U., Atta-ur-Rahman. (2004). Phenolic glycosides, a new class of human recombinant nucleotide pyrophosphatase phosphodiesterase-1 inhibitors. Bioorganic \& Medicinal Chemistry, 12 (22), 5793-5798. doi: 10.1016/j.bmc.2004.08.035

8. Khan, K. M., Fatima, N., Rasheed, M., Jalil, S., Ambreen, N., Perveen, S., Choudhary, M. I. (2009). 1,3,4-0xadiazole-2(3H)-thione and its analogues: A new class of non-competitive nucleotide pyrophosphatases/phosphodiesterases 1 inhibitors. Bioorganic \& Medicinal Chemistry, 17 (22), $7816-7822$. doi: 10.1016/j.bmc.2009.09.011

9. Khan, K. M., Siddiqui, S., Saleem, M., Taha, M., Saad, S. M., Perveen, S., Choudhary, M. I. (2014). Synthesis of triazole Schiff bases: Novel inhibitors of nucleotide pyrophosphatase/phosphodiesterase-1. Bioorganic \& Medicinal Chemistry, 22 (22), 6509-6514. doi: 10.1016/j.bmc.2014.08.032

10. Zalatan, J. G., Fenn, T. D., Brunger, A. T., Herschlag, D. (2006). Structural and Functional Comparisons of Nucleotide Pyrophosphatase/Phosphodiesterase and Alkaline Phosphatase: Implications for Mechanism and Evolution. Biochemistry, 45 (32), 9788-9803. doi: 10.1021/bi060847t

11. Vovk, A. I., Kalchenko, V. I., Cherenok, S. A., Kukhar, V. P., Muzychka, O. V., Lozynsky, M. O. (2004). Calix[4]arene methylenebisphosphonic acids as calf intestine alkaline phosphatase inhibitors. Organic \& Biomolecular Chemistry, 2 (21), 3162. doi: 10.1039/b409526j

12. Vovk, A. I., Kononets, L. A., Tanchuk, V. Y., Cherenok, S. O., Drapailo, A. B., Kalchenko, V. I., Kukhar, V. P. (2010). Inhibition of Yersinia protein tyrosine phos phatase by phosphonate derivatives of calixarenes. Bioorganic \& Medicinal Chemistry Letters, 20 (2), 483-487. doi: 10.1016/j.bmcl.2009.11.126

13. Vovk, A. I., Kononets, L. A., Tanchuk, V. Y., Drapailo, A. B., Kalchenko, V. I., Kukhar, V. P. (2009). Thiacalix[4]arene as molecular platform for design of alkaline phosphatase inhibitors. Journal of Inclusion Phenomena and Macrocyclic Chemistry, 66 (3-4), 271-277. doi: 10.1007/s10847-009-9607-9

14. Henz, S. L., Fürstenau, C. R., Chiarelli, R. A., Sarkis, J. J. F. (2007). Kinetic and biochemical characterization of an ecto-nucleotide pyrophosphatase/phosphodiesterase (EC 3.1.4.1) in cells cultured from submandibular salivary glands of rats. Archives of Oral Biology, 52 (10), 916-923. doi: 10.1016/j.archoralbio.2007.03.006

15. Wanno, B., Sang-aroon, W., Tuntulani, T., Polpoka, B., Ruangpornvisuti, V. (2003). Conformational and energetical structures of sulfonylcalix[4] arene, p-tert-butylsulfonylcalix[4]arene and their zinc complexes. Journal of Molecular Structure: Theochem, 629 (1-3), 137-150. doi: 10.1016/ s0166-1280(03)00135-0

16. Huey, R., Morris, G. M., Olson, A. J., Goodsell, D. S. (2007). A semiempirical free energy force field with charge-based desolvation. Journal of Computational Chemistry, 28 (6), 1145-1152. doi: 10.1002/jcc.20634

17. Hanwell, M. D., Curtis, D. E., Lonie, D. C., Vandermeersch, T., Zurek, E., Hutchison, G. R. (2012). Avogadro : an advanced semantic chemical editor, visualization, and analysis platform. Journal of Cheminformatics, 4 (1), 17. doi: 10.1186/1758-2946-4-17 
18. Biasini, M., Bienert, S., Waterhouse, A., Arnold, K., Studer, G., Schmidt, T., Schwede, T. (2014). SWISS-MODEL : modelling protein tertiary and quaternary structure using evolutionary information. Nucleic Acids Research, 42(W1), W252-W258. doi: 10.1093/nar/gku340

19. Šali, A., Blundell, T. L. (1993). Comparative Protein Modelling by Satisfaction of Spatial Restraints. Journal of Molecular Biology, 234 (3), $779-815$. doi: $10.1006 /$ jmbi.1993.1626

20. Jansen, S., Perrakis, A., Ulens, C., Winkler, C., Andries, M., Joosten, R. P., Bollen, M. (2012). Structure of NPP1, an Ectonucleotide Pyrophosphatase/ Phosphodiesterase Involved in Tissue Calcification. Structure, 20 (11), 1948-1959. doi: 10.1016/j.str.2012.09.001

21. Almi, M., Arduini, A., Casnati, A., Pochini, A., Ungaro, R. (1989). Chloromethylation of calixarenes and synthesis of new water soluble macrocyclic hosts. Tetrahedron, 45 (7), 2177-2182. doi: 10.1016/s0040-4020(01)80077-6

22. Kasyan, O., Swierczynski, D., Drapailo, A., Suwinska, K., Lipkowski, J., Kalchenko, V. (2003). Upper rim substituted thiacalix[4]arenes. Tetrahedron Letters, 44 (38), 7167-7170. doi: 10.1016/s0040-4039(03)01809-4

23. Kharchenko, S. G., Drapailo, A. B., Kalchenko, O. I., Yampolska, G. D., Shishkina, S. V., Shishkin, O. V., Kalchenko, V. I. (2013). Thia- and Sulfonyl-Calix[4]Arene Methylphosphonous Acids: Synthesis, Structure, and Amino Acids Binding. Phosphorus, Sulfur, and Silicon and the Related Elements, 188 (1-3), 243-248. doi: 10.1080/10426507.2012.741164

24. Iki, N., Kumagai, H., Morohashi, N., Ejima, K., Hasegawa, M., Miyanari, S., Miyano, S. (1998). Selective oxidation of thiacalix[4]arenes to the sulfinyl- and sulfonylcalix[4] arenes and their coordination ability to metal ions. Tetrahedron Letters, 39 (41), 7559-7562. doi: 10.1016/s0040-4039(98)01645-1

25. Kumagai, H., Hasegawa, M., Miyanari, S., Sugawa, Y., Sato, Y., Hori, T., Miyano, S. (1997). Facile synthesis of p-tert-butylthiacalix[4]arene by the reaction of p-tert-butylphenol with elemental sulfur in the presence of a base. Tetrahedron Letters, 38 (22), 3971-3972. doi: 10.1016/s0040-4039(97)00792-2

26. Kasyan, O., Kalchenko, V., Bolte, M., Böhmer, V. (2006). Hydrogen-bonded dimers of a thiacalixarene substituted by carbamoylmethylphosphineoxide groups at the wide rim. Chem. Commun., 18, 1932-1934. doi: 10.1039/b601016d 